\title{
IDENTIFIKASI BORAKS, FORMALIN SERTA PEWARNA BERACUN DAN BERBAHAYA MENUJU PRODUK MAKANAN SEHAT DAN HIGIENIS
}

\author{
Afifah Rosyidah ${ }^{*}$, Irmina Kris Murwani, Endang Purwanti dan Ratna Ediati \\ Departemen kimia, Institut Teknologi Sepuluh Nopember, \\ Kampus ITS Sukolilo-Surabaya 60111, Indonesia \\ *Email: afifah.chem@gmail.com
}

\begin{abstract}
ABSTRAK
Identifikasi dengan cara survey deskriptif dilakukan untuk identifikasi ada tidaknya boraks, formalin dan pewarna berbahaya pada makanan yang dijual oleh pedagang di Kelurahan Gebang Putih, Kelurahan Keputih dan lingkungan ITS ini merupakan bagian dari kegiatan pengabdian masyarakat berbasis penelitian. Sampel kios makanan diambil secara purposive dan accidental sampling dengan total 100 kios. Kandungan boraks, formalin dan pewarna berbahaya dianalisis secara kualitatif menggunakan test kit. Hasil yang diperoleh menunjukkan terdapat 3 sampel kios makanan yang positif menghidangkan makanan yang mengandung boraks; 2 sampel kios makanan yang menyajikan bakso dan mie mengandung formalin dan terdapat 1 sampel kios minuman yang positif mengandung pewarna berbahaya bagi kesehatan. Terhadap sampel kios penjual makanan dan minuman yang positif terindikasi boraks, formalin dan pewarna berbahaya, diberikan konseling dan bimbingan serta pengarahan tentang bahan alternatif pengganti yang aman untuk kesehatan.
\end{abstract}

Kata kunci: Boraks, Formalin, Pewarna Makanan dan Analisis Kualitatif

\section{PENDAHULUAN}

Jumlah PKL di Surabaya sepanjang waktu terus bertambah. Informasi yang diperoleh dari Dinas Koperasi dan Sektor Informal kota Surabaya, di Surabaya ada 19.000 PKL yang tersebar di 615 titik. Kehadiran PKL di satu sisi terkadang mengakibatkan kesemrawutan dan bahkan kemacetan jalan sehingga mengganggu ketertiban lalu lintas. Namun di sisi lain, PKL berpotensi menciptakan dan menambah lapangan kerja untuk masyarakat yang mempunyai tingkat pendidikan dan ketrampilan minim.

Keberadaan PKL dapat menimbulkan permasalahan yang kompleks. Terkadang aktivitasnya dapat mengganggu fasilitas umum seperti kelancaran lalu lintas, aspek keselamatan saat hilir mudik pembeli sehingga memungkinkan terjadinya kecelakaan; namun apabila PKL digusur maka masyarakat akan kesulitan untuk memenuhi sebagain besar kebutuhan hidupnya yang terutama disediakan oleh PKL; seperti aneka makanan dan minuman.

Kepuasan yang dicapai konsumen penikmat PKL ini terutama didasarkan atas harganya yang terjangkau kalangan menengah ke bawah. Keadaan tersebut mendorong PKL untuk senantiasa memenuhi kepuasan konsumen menggunakan berbagai cara. Perkembangan teknologi dan informasi saat ini dapat memicu penggunaan bahan tambahan pangan BTP seperti pengawet, penyedap, pewarna dan bahkan pengawet (Wijaya, 2011). Bahan pengawet digunakan dengan maksud untuk meningkatkan kekenyalan dan bahkan penampakan yang menarik sekaligus mendapatkan waktu simpan yang tahan lama (Cahyadi, W., dan Sukayada, 2008). Bahan Tambahan Pangan BTP yang diijinkan untuk ditambahkan ke dalam makanan sudah dinyatakan dalam Peraturan Menteri Kesehatan Republik Indonesia Nomor 722/Menkes/Per/IX/88 dan PERMENKES No. 33 Tahun 2012 (Depkes RI, 1988). Meski demikian, pengetahuan dan pemahaman yang terbatas dari PKL menyebabkan, penggunaan BTP yang dilarang masih banyak beredar dan ditemukan di pasaran 
bahkan dengan takaran yang melebihi ambang batas, terutama BTP yang berfungsi sebagai pengawet seperti formalin dan boraks.

Perkembangan pengetahuan, pemahaman dan teknologi yang semakin maju semakin menyadarkan konsumen akan pentingnya nilai gizi dan Bahan Tambahan Pangan yang ditambahkan pada makanan (Faradila, Elmatris, dan Yustini, 2013). Hal ini memotivasi pengabdi dan Tim untuk melakukan kegiatan pengabdian kepada masyarakat berbasis penelitian guna mengetahui ada tidaknya bahan tambahan pangan berbahaya pada makanan dan minuman yang dijual PKL.

Adapun alasan pemilihan lokasi pelaksanaan pengabdian kepada masyarakat ini didasarkan atas keseriusan mendukung dan menciptakan fungsi kelurahan Gebang Putih dan kelurahan Keputih sebagai kampung ekonomi yang mengembangkan hasil ekonomi lokal dalam bentuk produk unggulan yang sehat dan higienis. Konsep ini dilakukan untuk mendukung Visi dan Misi Pemerintah Daerah dalam mengembangkan potensi Sumber Daya yang ada dengan konsep semangat Otonomi Daerah (Rosyidah, A. , Purwanti E., Hartanto D., Murwani IK., Prasetyoko D., 2017). Selain itu, adanya informasi dari alumni yang menyatakan salah satu penyebab gagalnya diterima di perusahaan tertentu adalah akibat gagalnya tes kesehatan, meskipun IPK tinggi. Hal ini tidak lepas dari pengaruh konsumsi makanan sehari-hari yang sangat mungkin masih mengandung BTP yang dilarang. Karena dari hasil penelitian yang telah dilakukan di kelurahan Gebang Putih dan Keputih, masih ditemukan adanya beberapa pedagang "nakal" dengan menambahkan boraks, formalin atau pewarna berbahaya pada dagangannya. Dengan melakukan penelitian di PKL kelurahan Gebang Putih, Keputih dan lingkungan ITS serta memberi penjelasan dan pelatihan kepada para PKL tersebut, diharapkan pengetahuan tentang produk makanan dan minuman yang mengandung BTP terlarang terutama boraks, formalin dan pewarna berbahaya dapat dihindari dan sekaligus pemahaman serta pengetahuan yang telah diberikan dapat disebar luaskan ke masyarakat luas di sekitar lingkungannya.

\section{METODA}

\section{Alat}

Peralatan yang digunakan dalam penelitian yang dilakukan meliputi alat-alat gelas (tabung reaksi, erlenmeyer, gelas ukur, gelas beaker, pipet tetes, pipet ukur, gelas arloji), cawan porselen, batang pengaduk, mortar dan stemper, bunsen dan spiritus, neraca analitik, gunting, pinset, benang woll, spektrofotometer UV, spektrofometer serapan atom.

\section{Bahan}

Bahan-bahan kimia yang digunakan terdiri dari: natrium tetraboraks p.a, kalsium karbonat p.a, kertas saring whatman 42, kertas kurkuma, kertas tumerik, asam klorida p.a, asam sulfat p.a, Etanol 95\% (p.a), etil metil keton, dan aquademin. Sampel berupa makanan dan minuman yang dijual PKL

\section{Preparasi Sampel}

Sampel yang diperoleh ditempatkan dalam pack makanan atau minuman dan selanjutnya dilakukan analisis pada saat itu juga.

\section{Analisis kadar formalin secara spektrofotometri UV-Vis}

Pada tahap ini, yang dilakukan adalah menimbang 5 gram sampel untuk selanjutnya dihaluskan menggunakan mortar pestel. Sampel yang telah dilembutkan didistilasi menggunakan 100 $\mathrm{mL}$ aquademin. Destilat yang diperoleh ditambahkan reagen Nash's "B" dengan perbandingan 1:2 dan selanjutnya dipanaskan selama 30 menit pada suhu $37{ }^{\circ} \mathrm{C}$ menggunakan waterbath. Larutan 
blangko disiapkan antara aquademin dan reagen Nash's "B" dengan perbandingan 1:1. Absorbansi diukur pada $\lambda$ maks $415 \mathrm{~nm}$

\section{Analisis kadar boraks secara volumetri}

Analisis boraks secara volumetri dilakukan menggunakan konsep yaitu titrasi asam basa. Sampel makanan diambil sebanyak 18 gram untuk selanjutnya dihaluskan dan ditambahkan aquades. Sampel distirer menggunakan magnetik stirer selama 24 jam. Larutan sampel diambil sebanyak 25 $\mathrm{mL}$ kemudian diberi 2 tetes $\mathrm{HCl}$ pekat, ditambahkan manitol 0,2 gram dan indikator pp 2 tetes. Titrasi dilakukan menggunakan larutan $\mathrm{NaOH} \mathrm{0,1} \mathrm{M.} \mathrm{Volume} \mathrm{NaOH}$ yang digunakan untuk titrasi dicatat. Larutan blangko yang digunakan adalah aquades.

\section{Analisis Pewarna Makanan}

Adanya pewarna yang berbahaya pada makanan dilakukan dengan cara menimbang sampel sebanyak 10 gram dan ditambahkan $20 \mathrm{ml}$ larutan ammonia $2 \%$ selama 12 jam. Selanjutnya ditambahkan $5 \mathrm{~mL}$ larutan asam asetat 10\%. Benang wol dimasukkan hingga pewarnanya terserap dan dididihkan selama 10 menit. Selanjutnya benang wol tersebut dimasukkan ke dalam campuran alkohol $70 \%$ dan amonia 10\% hingga pewarnanya terlarut. Tahap akhir dilakukan analisis kromatografi lapis tipis (Hastuti, 2010).

\section{Penentuan Kadar Rhodamin B}

Penentuan kadar Rhodamin B dilakukan menggunakan plat KLT berukuran $20 \times 20 \mathrm{~cm}$ yang dipanaskan dalam oven $100^{\circ} \mathrm{C}$ selama setengan jam. Sedangkan fase gerak yang digunakan berupa n-butanol: etil asetat : ammonia (10:4:5). Sampel ditotolkan pada plat KLT dengan pipa kapiler 1,5 cm dari bawah plat, jarak antara penotolan noda adalah $2 \mathrm{~cm}$. Selanjutnya dibiarkan mengering. Kemudian dimasukkan kedalam chamber. Dibiarkan hingga terelusi sempurna, dikeringkan. Diamati warnanya menggunakan sinar UV. Apabila noda merah jambu yang diamati pada sinar UV $254 \mathrm{~nm}$ dan $366 \mathrm{~nm}$ berfluoresensi kuning atau orange, maka positif menunjukkan adanya rhodamin $B$ (Ditjen POM, 2001).

\section{HASIL DAN PEMBAHASAN}

Boraks telah menjadi momok bagi masyarakat Indonesia pada umumnya. Hal ini sangat beralasan karena boraks merupakan zat yang berbahaya bagi kesehatan manusia. Apabila sering mengonsumsi makanan yang mengandung boraks dapat menyebabkan gangguan metabolisme, ginjal, hati, dan otak. Bahkan apabila konsumsi terus dilakukan dalam kurun waktu yang lama dapat menyebabkan bahkan kematian (Djamhuri, 2009).

Ada kecenderungan para pembuat lontong yang diperdagangkan masih menggunakan bahan tambahan pangan berupa bleng atau boraks dengan harapan supaya teksturnya lebih kenyal dan tidak mudah basi. Tidak semua, namun masih ada sampel yang telah diuji masih terdeteksi mengandung boraks. Menurut EFSA, European Food Safety Authority, Lembaga Pemerintah Uni Eropa untuk Keamanan Makanan (2013), kadar tertinggi (maximum level) boraks dalam makanan sekitar 4mg/kg (Mahdi, 2008).

Hasil pengujian selanjutnya terhadap adanya formalin dilakukan pada sampel mie basah dan bakso yang positif mengandung formalin. Keadaan ini ditandai dengan hilangnya warna pink pada saat pemberian $\mathrm{KMnO}_{4}$ (Merck, Germany). Adapun hasil uji kualitatif terhadap bihun, tahu, siomay, sosis dan lontong tidak menunjukkan ada perubahan warna ketika diberi $\mathrm{KMnO}_{4}$. Kondisi ini menunjukkan bahwa tidak terdapat formalin pada sejumlah makanan tersebut.

Formalin merupakan kelompok senyawa aldehid atau alkanal, yang mempunyai satu atom karbon, umumnya berupa larutan formaldehid 40 \% (Alsuhendra \& Ridawati, 2013). Lembaga 
Internasional untuk penelitian kanker (IARC) dan Lembaga perlindungan lingkungan Amerika Serikat (EPA), mengelompokkan formalin sebagai senyawa karsinogen, yaitu senyawa yang memicu kanker (Widyaningsih, T.D., dan Murtini, 2006). Formalin termasuk dalam kelompok desinfektan yang efektif dan efisien. Pada bidang perindustrian banyak diproduksi sebagai pembersih lantai, pengawet tekstil dan pembasmi kuman dan serangga alias pestisida.

Hasil pemeriksaan terhadap penggunaa formalin pada makanan yang dijual di wilayah kuliner PKL sekitar Kelurahan Gebang Putih, Kelurahan Keputih dan sekitar kampus ITS menunjukkan bahwa masih ada sampel yang positif mengandung formalin. Menurut International Programe on Chemical Safety, ambang batas toleransi formalin yang bisa diterima oleh badan adalah 0,1 miligram perliter. Apabila konsumen terus-menerus mengkonsumsi makanan yang mengandung formalin, maka sistem metabolisme akan rusak dan mengakibatkan pembengkakan serta radang paru-paru bahkan dapat menyebabkan kematian (Saptarini, N,, Wardati, Y., dan Supriatna, 2011).

Sedangkan untuk bahan pewarna, Departemen Kesehatan (Depkes) RI merekomendasi 1,25$1,5 \mathrm{mg} / \mathrm{kg}$ berat badan (merah), 2,5 mg/kg, berat badan (biru), $12,5 \mathrm{mg} / \mathrm{kg}$ berat badan (hijau), dan 5-7,5 mg/kg (kuning) dengan kadar arsen tidak melebihi 0,00014\% dan kadar timbal tidak melebihi 0,001\% (Trestiati, 2003).

Pewarna Rhodamine B memberikan warna merah sedangkan Metanil Yellow menghasilkan warna kuning, yang mana pewarna jenis ini biasa digunakan untuk mewarnai kertas, tinta, tekstil, vernis dan beberapa produk mainan anak-anak (Nollet, 2004). Rhodamin B, dengan rumus kimia $\mathrm{C}_{28} \mathrm{H}_{31} \mathrm{ClN}_{2} \mathrm{O}_{3}$ mempunyai titik lebur $165^{\circ} \mathrm{C}$. Rodamine $\mathrm{B}$ berasal dari senyawa Metaliniat dan Dipanel Alanin sifatnya sangat mudah larut dalam alkohol dan air (Jana, 2007). Struktur Rhodamin B dapat dinyatakan pada Gambar 1 berikut.

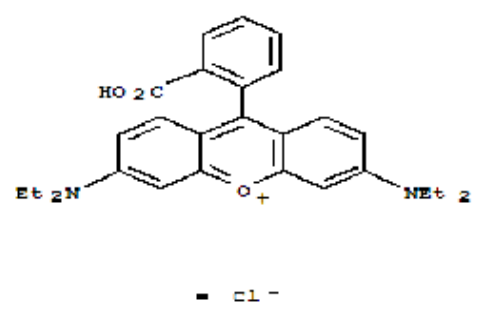

Gambar 1: Rhodamin B

Hasil identifikasi boraks, formalin dan pewarna berbahaya pada makanan serta minuman disajikan dalam Gambar 2.

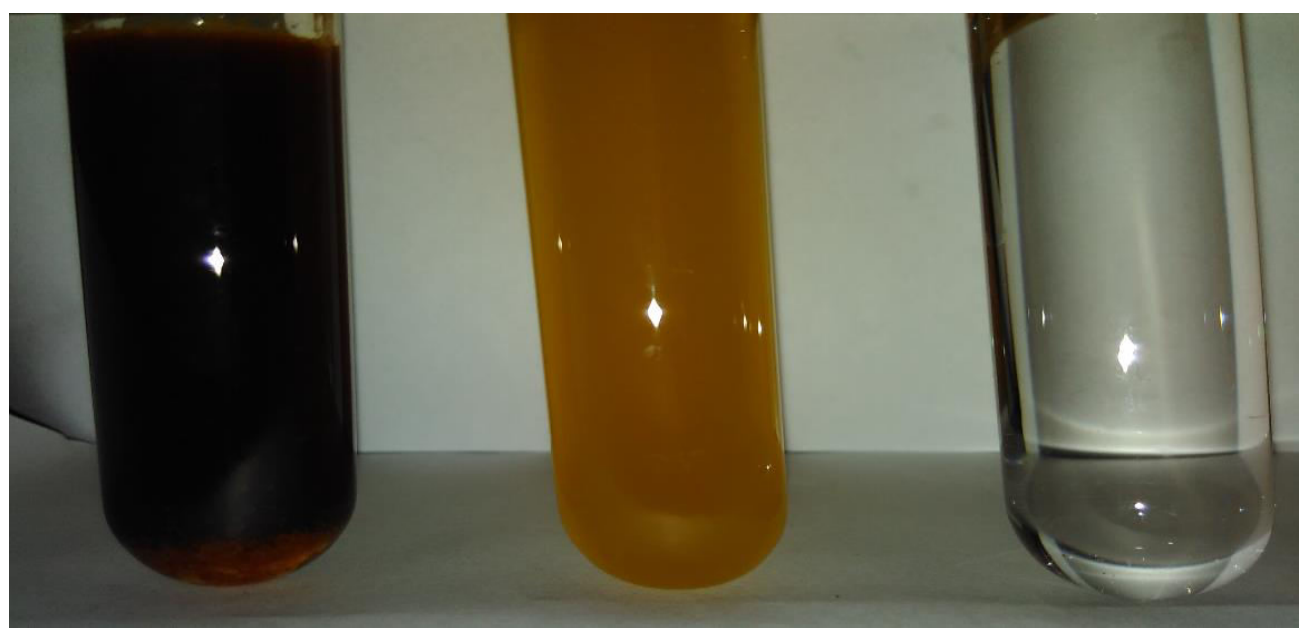

(a) 


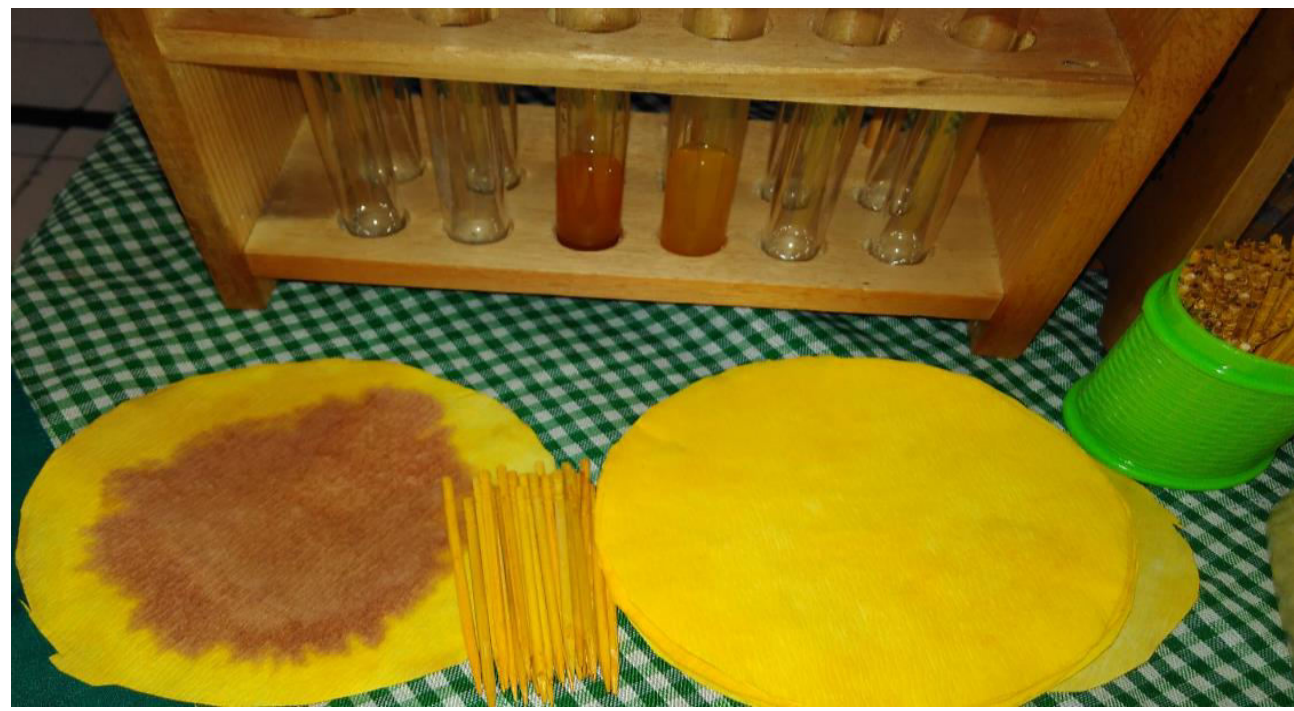

(b)
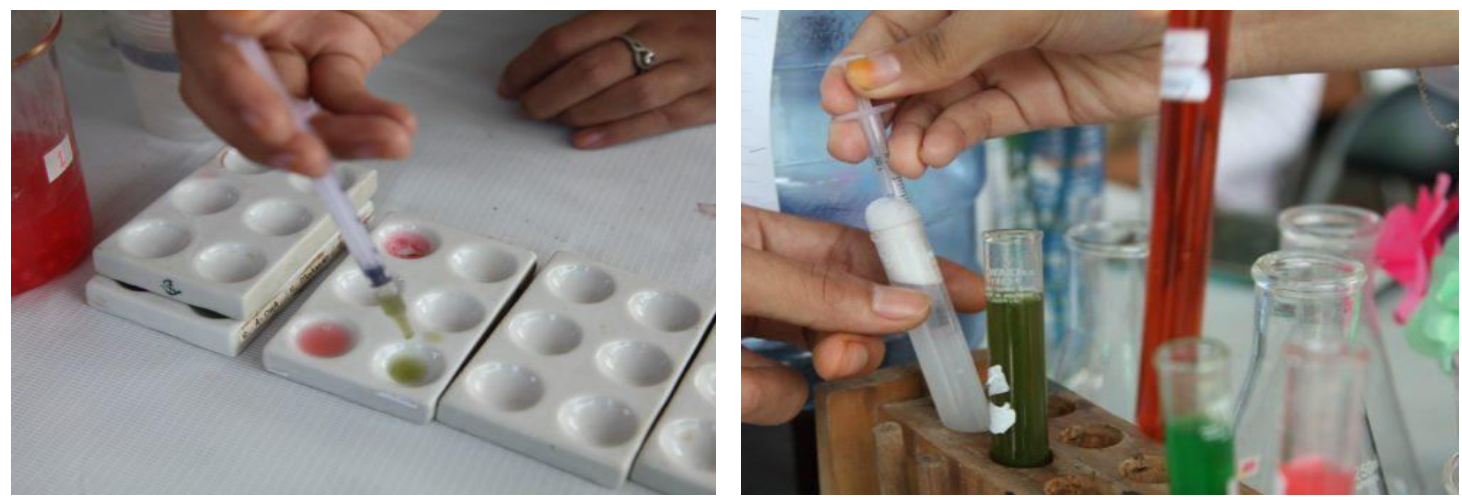

(c)

Gambar 2: Pengujian Boraks (a); Pengujian Formalin (b) dan Pengujian Pewarna Makanan (c)

Makanan atau minuman yang diberi Rhodamin B, menghasilkan warna yang sangat mencolok atau sangat cerah sehingga nampak menarik. Namun pengaruh lain dari Rhodamin $B$ adalah timbulnya rasa pahit dan getir serta gatal di tenggorokan bahkan dapat menimbulkan iritasi serta keracunan pada saluran kencing (Djalil, A.D., Hartanti, D., Rahayu, W.S., Prihatin, R., Hidayah, 2005).

Terdapat beberapa bahan alami yang dapat menggantikan fungsi sebagai pengawet, pengenyal dan pewarna pada makanan serta minuman. Bahan alami ini selain mudah diperoleh juga lebih aman untuk kesehatan. Bahan tersebut adalah kitosan, rumput laut, tepung sagu atau tepung tapioka, air rendaman abu merang atau klaras serta air kapur sirih (Donatus, 1990). Bahan-bahan tersebut selain mudah didapat atau dibuat juga sangat aman bagi kesehatan; yang dapat berfungsi sebagai pengawet serta pengenyal makanan. Sedangkan pewarna alami bisa didapatkan dari daun jati untuk warna merah hingga coklat, dau pandan suji untuk warna hijau serta kunyit untuk warna kuning hingga orange. 


\section{KESIMPULAN}

Berdasarkan hasil yang telah diperoleh serta pembahasan yang telah dilakukan di atas, dapat ditarik beberapa kesimpulan bahwa untuk beberapa penjual makanan dan minuman yang ada di Kelurahan Gebang Putih, Kelurahan Keputih serta lingkungan sekitar ITS masih ditemukan adanya pedagang yang "nakal" dengan menambahkan bahan kimia berbahaya pada makanan atau minuman. Terhadapnya senantiasa diberikan pemahaman dan pengertian supaya hal tersebut tidak terjadi lagi. Penyuluhan dan Pembinaan senantiasa dilakukan untuk mencapai tujuan terciptanya produk makanan dan minuman yang sehat dan higienis.

\section{DAFTAR PUSTAKA}

Alsuhendra, \& Ridawati. (2013). Bahan toksik dalam makanan. Jakarta: Rosda.

Cahyadi, W., dan Sukayada, I. M. . (2008). Analisis dan Aspek Kesehatan Bahan Tambahan Pangan. Jakarta: Bumi Aksara.

Depkes RI. Peraturan Mentri Kesehatan Repulik Indonesia No.722/Menkes/IX/1988. Tentang Badan Tambahan Makanan, Pub. L. No. No.722/Menkes/IX/1988 (1988). Indonesia.

Djalil, A.D., Hartanti, D., Rahayu, W.S., Prihatin, R., Hidayah, N. (2005). Identfikasi Zat Warna Kuning Metanil (Metanil Yellow) dengan Metode Kromatografi Lapis Tipis (KLT) pada Berbagai Komposisi Larutan Pengembang. Jurnal Farmasi.

Djamhuri, A. (2009). Racun dalam Makanan. Surabaya: Airlangga University Press.

Donatus, I. A. (1990). Toksikologi Pangan, PAU Pangan dan Gizi. Yogyakarta: UGM.

Faradila, Elmatris, dan Yustini, A. (2013). Identifikasi Formalin pada Bakso yang Dijual pada Beberapa Tempat di Kota Padang. Jurnal Kesehatan Andalas, 3(2), 156-158.

Hastuti, S. (2010). Analisis kualitatif dan Kuantitatif Formaldehid Pada Ikan Asin di Madura. Jurnal Agrointek, 4(2), 132-137.

Jana, J. (2007). Studi Penggunaan Pewarna Sintetis (Sunset Yellow, Tartrazine dan Rhodamin B) Pada Beberapa Produk Pangan di Kabupaten Sukabumi. Sukabumi.

Mahdi, C. (2008). Mengenal Berbagai Produk Reagen Kit Tester Untuk Uji Formalin, Borak, Zat Pewarna Berbahaya dan Kandungan Yodium Pada Garam Beryodium. Malang: Universitas Brawijaya Malang.

Nollet. (2004). Analisa Rhodamin B dan Metanil Yellow dalam Minuman Jajanan Anak SD di Kecamatan Laweyan Kotamadya Surakarta Metode Kromatografi Lapis Tipis. Universitas Muhamadiyah Surakarta.

Rosyidah, A. , Purwanti E., Hartanto D., Murwani IK., Prasetyoko D., dan E. R. (2017). Penataan PkI Bebas Boraks Dan Formalin Menuju Produk Unggulan Sehat Dan Higienis. Qardhul Hasan: Media Pengabdian Kepada Masyarakat, 3(2), 86-98.

Saptarini, N,, Wardati, Y., dan Supriatna, U. (2011). Deteksi Formalin dalam Tahu di Pasar Tradisional Purwakarta. Bandung: Universitas Padjadjaran.

Trestiati, M. (2003). Analisis Rhodamin B pada Makanan dan Minuman Jajanan Anak SD (Studi Kasus : Sekolah Dasar di Kecamatan Margaasih Kabupaten Bandung). ITB.

Widyaningsih, T.D., dan Murtini, E. S. (2006). Alternatif Pengganti Formalin pada Produk Pangan, Identifikasi Formalin Pada Bakso Dari Pedagang Bakso Di Kecamatan Panakukkang. Makassar.

Wijaya, D. (2011). Waspadai Zat Aditif dalam Makananmu. Jogjakarta: Bukubiru. 